\begin{tabular}{|c|l|}
\hline Title & Surface Passivation of A IGaN GaN Heterostructures Using an U Itrathin A I 20 3 Layer \\
\hline Author(s) & Ootomo, S.; Hashizume, T.; Hasegawa, H. \\
\hline Citation & $\begin{array}{l}\text { Physica Status Solidi (a), 188(1), 371-374 } \\
\text { https://doi.org/10.1002/1521-396X (200111)188:1<371::A ID-PSSA 371>3.0.c0;2-P }\end{array}$ \\
\hline Issue Date & 2001-11-22 \\
\hline Doc URL & http://hdl.handle.net/2115/5600 \\
\hline Type & article \\
\hline Note & Published in physica status solidi (a), 2001, Wiiley-V VH V erlag GmbH \& Co. KGaA, Weinheim \\
\hline File Information & PSSA 188 1.pdf \\
\hline
\end{tabular}

Instructions for use 


\title{
Surface Passivation of AlGaN/GaN Heterostructures Using An Ultrathin $\mathrm{Al}_{2} \mathrm{O}_{3}$ Layer
}

\author{
SHINYA OOTOMO ${ }^{1)}$, TAMOTSU HASHIZUME and HigEKI HASEGAWA \\ Research Center for Integrated quantum Electronics (RCIQE), and Graduate School of \\ Electronics and Information Engineering, Hokkaido University, kita-ku N13W8, 060-8628 \\ Sapporo, Japan
}

(Submitted June 21, 2001)

Subject classification: $73.40 . Q v$

\begin{abstract}
We demonstrate a novel surface passivation process for $\mathrm{AlGaN} / \mathrm{GaN}$ heterostructures utilizing an ultrathin $\mathrm{Al}_{2} \mathrm{O}_{3}$ layer $(\sim 1 \mathrm{~nm})$. The $\mathrm{Al}$ deposition and the thermal annealing processes in UHV were found to form the ultrathin $\mathrm{Al}_{2} \mathrm{O}_{3}$ layer on the surface of the $\mathrm{AlGaN} / \mathrm{GaN}$ heterostructure, which was confirmed by in-situ $\mathrm{x}$-ray photoelectron spectroscopy (XPS) analysis. The reverse leakage current for the Schottky gate contact on the $\mathrm{Al}_{2} \mathrm{O}_{3}$-passivated heterostructure surface was reduced by three orders of magnitude than that for the conventional Schottky gate structure. C-V results showed good gate controllability of two-dimensional electron gas (2DEG) by the novel gate structure.
\end{abstract}

\section{Introduction}

The AlGaN/GaN heterostructure field effect transistors (HFETs) have been key electronic devices for high-power applications at microwave/millimeter-wave frequencies. Although there have been a lot of reports on excellent frequency and power performances of $\mathrm{AlGaN} / \mathrm{GaN}$ HFETs, they have suffered from surface/interface-related problems. For example, they have a large gate leakage current [1,2], aging of Schottky contacts to AlGaN [3] and frequency dispersion in drain current [4], etc. In order to overcome these problems, it is essentially indispensable to understand the $\mathrm{AlGaN} / \mathrm{GaN}$ heterostructure surfaces and to realize a suitable surface passivation process.

In this paper, we demonstrate a novel surface passivation process for $\mathrm{AlGaN} / \mathrm{GaN}$ heterostructures utilizing an ultrathin $\mathrm{Al}_{2} \mathrm{O}_{3}$ layer. The formation process of an ultrathin $\mathrm{Al}_{2} \mathrm{O}_{3}$ layer was characterized and optimized by x-ray photoelectron spectroscopy (XPS) method. The passivation effect of an ultrathin $\mathrm{Al}_{2} \mathrm{O}_{3}$ layer was examined in terms of currentvoltage $(\mathrm{I}-\mathrm{V})$ and capacitance-voltage $(\mathrm{C}-\mathrm{V})$ characteristics for the metal/ultrathin$\mathrm{Al}_{2} \mathrm{O}_{3} / \mathrm{AlGaN}$ gate structure.

\section{AlGaN/GaN heterostructure sample}

The AlGaN/GaN heterostructure wafers grown on (0001) sapphire substrates by metalorganic vapor phase epitaxy (MOVPE), as shown in Fig. 1, were used in this study. The Hall mobility and sheet carrier concentration of the two-dimensional electron gas (2DEG) formed at the AlGaN/GaN heterointerface were $1300 \mathrm{~cm}^{2} / \mathrm{Vs}$ and $1.5 \times 10^{13} \mathrm{~cm}^{-2}$ at room temperature (RT), and $5700 \mathrm{~cm}^{2} / \mathrm{Vs}$ and $1.2 \times 10^{13} \mathrm{~cm}^{-2}$ at $77 \mathrm{~K}$, respectively.

\footnotetext{
1) Corresponding author; Phone: +81 11706 7174, Fax: +81 11716 6004, e-mail: ootomo@rciqe.hokudai.ac.jp
} 


\begin{tabular}{|c|}
\hline $\mathrm{Al}_{0.25} \mathrm{Ga}_{0.75} \mathrm{~N}(3 \mathrm{~nm})$ \\
\hline $\mathrm{n}^{+-} \mathrm{Al}_{0.25} \mathrm{Ga}_{0.75} \mathrm{~N}(25 \mathrm{~nm})$ \\
\hline $\mathrm{Al}_{0.25} \mathrm{Ga}_{0.75} \mathrm{~N}(3 \mathrm{~nm})$ \\
\hline $\mathbf{G a N}(2 \mu \mathrm{m})$ \\
\hline $\mathrm{GaN} \mathrm{LT}$ buffer $(20 \mathrm{~nm})$ \\
\hline Sapphire substrate \\
\hline
\end{tabular}

Fig. 1. The AlGaN/GaN heterostructure sample

\section{Results and Discussion}

\subsection{XPS analysis on passivated AlGaN/GaN heterostructure surfaces}

Detailed XPS analysis showed that the air-exposed AlGaN/GaN heterostructure surface possessed highly non-stoichiometric phase with large amounts of natural oxide $[5,6]$. The wet chemical treatment in the $\mathrm{NH}_{4} \mathrm{OH}$ solution at $50^{\circ} \mathrm{C}$ was found to be very effective in reducing the natural oxide layer on the surface of the as-grown AlGaN/GaN heterostructure wafer. However, there remained a small amount of natural oxide including $\mathrm{Al}_{2} \mathrm{O}_{3}$ and $\mathrm{Ga}_{2} \mathrm{O}_{3}$ components even on the $\mathrm{NH}_{4} \mathrm{OH}$-treated surface.

To control such a surface, we attempted to form an ultrathin $\mathrm{Al}_{2} \mathrm{O}_{3}$ passivation layer by the following process. First, ultrathin $(1 \mathrm{~nm})$ Al layer was deposited on the $\mathrm{NH}_{4} \mathrm{OH}$-treated AlGaN surface at RT using a K-cell with a rate of $0.01 \mathrm{~nm} / \mathrm{s}$ in an MBE chamber $\left(3 \times 10^{-10}\right.$ Torr). Then, the sample was annealed at $800^{\circ} \mathrm{C}$ for $10 \mathrm{~min}$ in UHV annealing system. The basic idea of this process is to convert the natural oxide on the AlGaN surface to the $\mathrm{Al}$ oxide $\left(\mathrm{Al}_{2} \mathrm{O}_{3}\right)$ by use of the reaction with an active metallic Al. The novel passivation process was optimized by in-situ XPS analysis.

Figure 2(a) shows in-situ XPS Al $2 p$ spectra taken from the Al-deposited surface with escape angle of $10^{\circ}$ and $60^{\circ}$. The Al-O bonding peaks were detected in addition to the metallic $\mathrm{Al}$ and $\mathrm{AlGaN}$ peaks, in spite of the fact that the Al deposition was done in UHV. From the angle-resolved XPS analysis of the A1 $2 p$ peak, an Al-oxide was found to grow at the $\mathrm{Al} / \mathrm{AlGaN}$ interface, indicating the reaction between metallic $\mathrm{Al}$ and residual natural oxide during the deposition process. After the UHV anneal at $800^{\circ} \mathrm{C}$ for $10 \mathrm{~min}$, the metallic Al peak disappeared in the Al $2 p$ spectra, as shown in Fig. 2(b). The Al $2 p$ spectra could be deconvoluted into the two peaks assigned to the bulk AlGaN peak and the topmost Al-oxide peak. The Al-O bonding peak position is very close to that of the $\mathrm{Al}_{2} \mathrm{O}_{3}$ phase. The integrated intensity ratio of the $\mathrm{O} 1 \mathrm{~s} / \mathrm{Al} 2 p(\mathrm{Al}-\mathrm{O})$ was 5.7, also close to the value of reference sapphire $\left(\mathrm{Al}_{2} \mathrm{O}_{3}\right)$ substrate. In addition, the peak intensity of $\mathrm{Ga}_{2} \mathrm{O}_{3}$ component in the $\mathrm{Ga} 3 d$ spectra was found to decrease after the UHV annealing process. Thus, this annealing process enhanced the reaction between metallic $\mathrm{Al}$ and residual natural oxide, resulting in the formation of the ultrathin $\mathrm{Al}_{2} \mathrm{O}_{3}$ layer. The thickness of the ultrathin $\mathrm{Al}_{2} \mathrm{O}_{3}$ layer was estimated to be $1.2 \mathrm{~nm}$.

Figure 3(a) shows the XPS O1 $s$ spectrum obtained from the $\mathrm{Al}_{2} \mathrm{O}_{3} / \mathrm{AlGaN}$ sample. The energy loss signal exhibited a rather broad peak at the higher binding energy side away from the $\mathrm{O} 1 s$ core-level energy position. From the onset of the $\mathrm{O} 1 s$ energy loss signal seen in Fig. $3(\mathrm{~b})$, the energy gap $\left(E_{\mathrm{g}}\right)$ of the ultrathin $\mathrm{Al}_{2} \mathrm{O}_{3}$ layer was estimated to be $6.1 \mathrm{eV}$, suitable for a surface passivation of $\mathrm{AlGaN}\left(E_{\mathrm{g}} \sim 4.0 \mathrm{eV}\right)$. Almost the same value for the $\mathrm{Al}_{2} \mathrm{O}_{3}$ film on the 
Si (100) substrate was reported by Itokawa et al. [7].
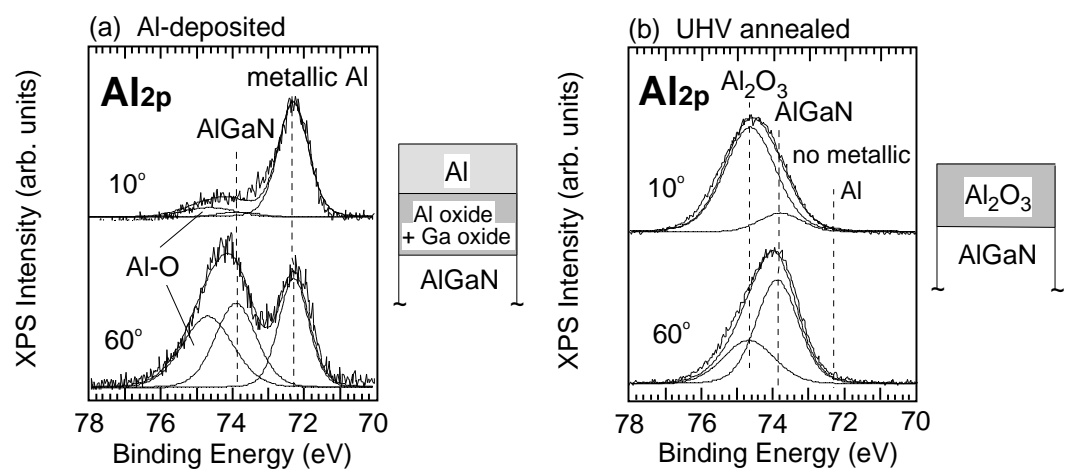

Fig. 2. XPS Al2p spectra of the $\mathrm{NH}_{4} \mathrm{OH}$-treated surface with escape angle of $10^{\circ}$ and $60^{\circ}$ after (a) the $\mathrm{Al}$ deposition at RT and (b) subsequent UHV annealing at $800^{\circ} \mathrm{C}$ for $10 \mathrm{~min}$.

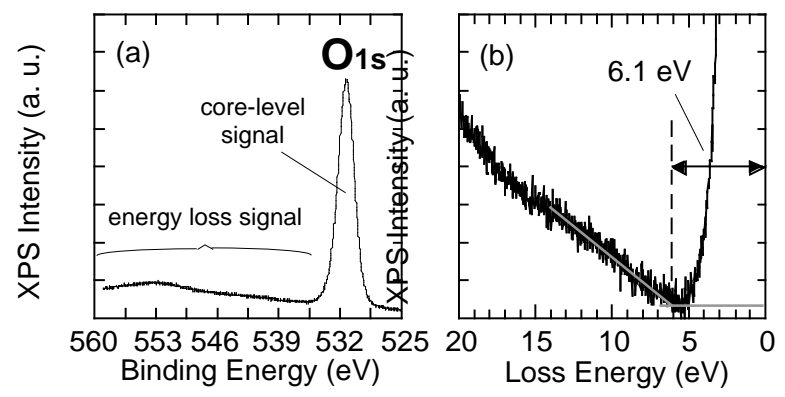

Fig. 3. (a) The XPS O1s spectrum obtained from the $\mathrm{Al}_{2} \mathrm{O}_{3} / \mathrm{AlGaN}$ sample and (b) the energy loss spectrum with respect to the $\mathrm{O} 1 s$ core-level position

3.2 Electrical properties of Pt Schottky contacts to the ultrathin- $\mathrm{Al}_{2} \mathrm{O}_{3}$ passivated surfaces.

The passivation effect of the ultrathin $\mathrm{Al}_{2} \mathrm{O}_{3}$ layer was examined in terms of $\mathrm{I}-\mathrm{V}$ and $\mathrm{C}-\mathrm{V}$ characteristics for the novel $\mathrm{Pt} / \mathrm{Al}_{2} \mathrm{O}_{3}$ Schottky gate structure. The ring-shaped Ti/Al/Ti/Au $(=20 / 80 / 20 / 50 \mathrm{~nm})$ ohmic electrodes were formed on the heterostructure surface, which surrounded the Pt gate electrode. The annealing of the ohmic contacts was performed at $600^{\circ} \mathrm{C}$ for $2 \min$ in $\mathrm{N}_{2}$ ambient.

Figure 4 compares the I-V characteristics for the novel $\mathrm{Pt} / \mathrm{Al}_{2} \mathrm{O}_{3}$ and the conventional $\mathrm{Pt}$ Schottky gate structures. The novel gate structure showed relatively small ideality factor of 1.17, similar to the conventional Schottky gate contact. This indicated that the current transport basically through the Schottky barrier was not significantly modified by the insertion of the ultrathin $\mathrm{Al}_{2} \mathrm{O}_{3}$ layer because the $\mathrm{Al}_{2} \mathrm{O}_{3}$ layer is very thin $(\sim 1 \mathrm{~nm})$. For the conventional Schottky gate sample, the I-V characteristics exhibited the very leaky (ohmiclike) behavior in the bias region from $-0.1 \mathrm{~V}$ to $0.1 \mathrm{~V}$. In comparison, the rectifying characteristic was significantly improved for the novel $\mathrm{Pt} / \mathrm{Al}_{2} \mathrm{O}_{3}$ structure, as shown in the dotted curve in Fig. 4. Furthermore, the reverse gate leakage current at $\mathrm{V}_{\mathrm{g}}=-5 \mathrm{~V}$ was reduced by three orders of magnitude than the conventional Schottky gate structures.

From the C-V measurement, we evaluated the controllability of the depletion layer for 
the $\mathrm{Pt} / \mathrm{Al}_{2} \mathrm{O}_{3}$ gate structure. The obtained capacitance value at zero bias was in agreement with the calculated one from the thickness of AlGaN layer $(31 \mathrm{~nm})$. No noticeable hysterisis and frequency dispersion were observed in $\mathrm{C}-\mathrm{V}$ characteristics at $10 \mathrm{kHz}-1 \mathrm{MHz}$, and clear pinch-off behavior was obtained. These results indicated that the good gate control of the depletion layer at $\mathrm{AlGaN} / \mathrm{GaN}$ heterointerface was achieved by the present $\mathrm{Pt} / \mathrm{Al}_{2} \mathrm{O}_{3}$ gate structure.

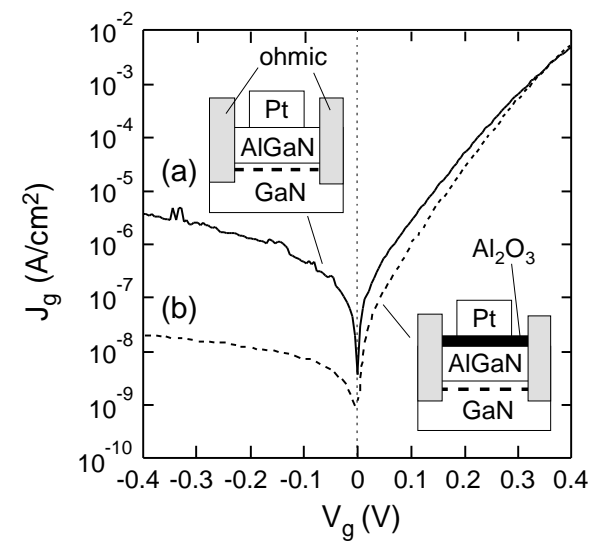

Fig.4 The I-V characteristics for (a) a conventional Schottky and (b) a novel $\mathrm{Pt} / \mathrm{Al}_{2} \mathrm{O}_{3}$ gate structures

\section{Conclusion}

A novel surface passivation process for $\mathrm{AlGaN} / \mathrm{GaN}$ heterostructures utilizing an ultrathin $\mathrm{Al}_{2} \mathrm{O}_{3}$ layer was demonstrated. The combination of the $\mathrm{Al}$ deposition and the annealing processes in UHV achieved the formation of the ultrathin $\mathrm{Al}_{2} \mathrm{O}_{3}$ layer on the surface of the $\mathrm{AlGaN} / \mathrm{GaN}$ heterostructure. The formation process of the $\mathrm{Al}_{2} \mathrm{O}_{3}$ passivation layer was optimized by in-situ XPS. The reverse gate leakage in the novel $\mathrm{Pt} / \mathrm{Al}_{2} \mathrm{O}_{3}$ gate structure was reduced by three orders of magnitude than the conventional Pt Schottky structure. In addition, the $\mathrm{Pt} / \mathrm{Al}_{2} \mathrm{O}_{3}$ gate structure exhibited good gate controllability of $2 \mathrm{DEG}$. Thus the present passivation process is promising for realizing reproducibility of device fabrication process and reliability of device operation.

\section{References}

[1] M. A. Khan, X. Hu, A. Tarakj, G. Simin, J. Yang, R. Gaska, and M. S. Shur, Appl. phys. Lett. 77, 1339 (2000).

[2] E. J. Miller, X. Z. DANG, and E. T. Yu, J. Appl. phys. 88, 5951 (2000).

[3] E. D. Readinger, B. P. Luther, S. E. Mohney, and E. L. Piner, J. Appl. phys. 89, 7983 (2001).

[4] B. M. Green, K. K. Chu, E. M. Chumbes, J. A. Smart, J. M. Shealy, and L. F. Eastman, IEEE Electron Device Lett. 21, 268 (2000).

[5] T. Hashizume, S. OоTOMo, R. NAKAsaki, S. Oyama, and M. Kinara; Appl. phys. Lett. 76, 2880 (2000).

[6] S. Оотомo, T. Hashizume, and H. Hasegawa; Proc. Int. Workshop on Nitride Semiconductor (IWN2000), Nagoya, 2000, IPAP Conf. Ser. No. 1, pp. 934-937.

[7] H. Itokawa, T. Maruyama, S. Miyazaki, and M. Hirose, Ext. Abst. of the 1999 Int. Conf. on Solid State Device and Materials (SSDM99), Tokyo, 1999, pp. 158-159. 